\section{Go-ahead for Danube}

THE controversial Gabcikovo-Nagymaros hydroengineering project on the Danube, halted last February under pressure from Hungarian environmentalists, is to go ahead. But the Hungarian government has pledged itself to "take into consideration" the recommendations of an expert committee, whose members include representatives of the Hungarian Academy of Sciences and the National Council for the Environment and Nature Protection. At the same time, the cooperation agreement between the Czechoslovak and Hungarian academies will be extended to include long-term monitoring of the environmental effects of the dam. Revised completion dates for the hydroengineering projects have been set at 1980 for the 720 MW facility at Gabcikovo, 1193 for the 160 MW Nagymaros plant, and 1995 for overall completion. Both dams are intended to serve as peak-hour generators, both countries being committed to nuclear power for round-the-clock supplies.

The Czechoslovak side has always been keener on the completion of the project, principally because of the benefits from the flood-control effects; the damage to the water table of northern Hungary, on the other hand, may cost more to remedy (by providing alternative drinking water supplies) than the estimated saving in energy costs. There is also the considerable psychological factor (for the Hungarians) that, as a result of the scheme, the main navigational channel of the Danube, which at present forms the international frontier between Czechoslovakia and Hungary, will be diverted into Czechoslovak territory, while the course of the frontier will be marked by a virtually dry ditch. Furthermore, the major part of the electricity generated will accrue to Czechoslovakia from the Gabcikovo dam, whereas the main purpose of the Nagymaros installation is to contain the surges from Gabcikovo,

The latest plans, apparently, no longer demand that the Nagymaros dam should be in itself cost-effective. Hungary has no oil or coal that could be used to fuel peakhour generators, and the only available

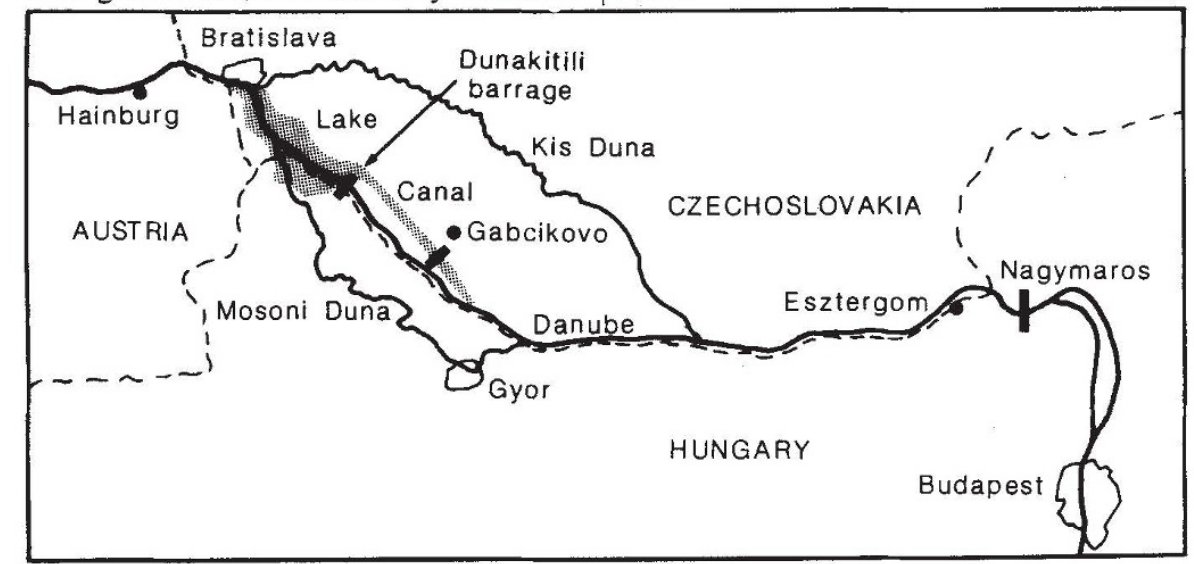

domestic fossil fuel, lignite, would, the government claims, be more harmful to the environment than would the dam.

Two years will be spent monitoring existing conditions of both river and ground-water before any overall movement of water is implemented, with a further year of monitoring once water movement starts. There are likely to be sewage works, and household and irrigation water for the affected areas.

One major objection to the project, however, remains unanswered: the threat to the flora and fauna of the Danube and its bayoux due to the construction of the storage reservoir at Gabcikovo and the diversion of some $25 \mathrm{~km}$ of its flow through an artificial concrete channel. Nor, specifically, have there been any assurances to the inhabitants of the settlements downstream from Gabcikovo, who fear that, if the Czechoslovak dam were to be breached by an earthquake (the site is a seismic zone), there would be extensive flooding as far downstream as Budapest.

Public opinion in Hungary thus seems

\section{Second front}

WHILE pressing for the implementation of the Gabcikovo-Nagymaros project, the Czechoslovak government has consistently castigated the Austrians for their "unilateral" decision to build a similar hydroelectric station at Hainburg, just upstream of the joint Austrian-Czechoslovak section of the river. The Hainburg dam was halted last winter under pressure from Austrian environmentalists, but the Czechoslovak government decided to take advantage of the friction to resume "active contacts" with Austria (after a gap of 25 years) on the use of the joint section. A protocol signed between the two sides in Vienna last week instructs a group of experts to formulate a programme, taking into account the "justified requirements and interests" of both states, the needs of international shipping and the environmental problems of the area, while making the fullest possible use of the hydroelectric potential of the river. Vera Rich unconvinced by the assurances of a government which, it believes, has been separately trying to withdraw from the project since 1981, but which has been unable to do more than buy time for its Czechoslovak partner. The clamp-down on media discussion of the project, early in 1984, was accompanied by what seemed to be carefully leaked rumours that $\mathrm{Mr}$ Kadar was trying to negotiate a Hungarian withdrawal by "quiet diplomacy".

The announcement that the project would after all go ahead has, perhaps unjustifiably, generated considerable disappointment. Vera Rich

\section{Estonian radioactivity}

\section{Lax handling of Soviet fuel}

POOR safety precautions at a nuclear waste dump in Estonia have caused the death of at least one worker, according to an Estonian engineer who defected to Sweden last year. The defector, who had temporarily worked at the Saku nuclear dump some $15 \mathrm{~km}$ south-east of Tallinn, last week told a reporter from the $S y d s$ venska Dagbladed that the dump consists of a simple concrete bunker in the forest, which is leaking waste. Radioactive material is brought to the dump in trucks that are not properly equipped for the transport of hazardous cargo. Radiationrelated disease is therefore common among those who have to service or transport material to the dump.

This is not the first time that reports of radiation sickness in Estonia have reached Sweden. Some three years ago, dissident Estonian sources claimed that it was endemic among the forced labourers employed to clean nuclear submarines at the Paldiski naval base.

Nuclear safety is an emotive issue in Estonia. For some years it has been thought that fuel for Finland's Soviet-built nuclear power stations is transported by rail to Tallinn and then shipped to $\mathrm{Hel}$ sinki, and that spent fuel is returned by the same route, using routine facilities. The intensive civil defence training enforced in border areas of the Soviet Union means that every inhabitant of Estonia is constantly reminded of the dangers of radioactive contamination, while the presence of nuclear submarines at the Paldiski and Naissar bases is viewed by many Estonians as an infringement of the sovereignty of their republic. Four years ago, a group of human rights activists from Lithuania, Latvia and Estonia wrote an open letter to the heads of the governments of the Soviet Union, Iceland, Norway, Denmark, Sweden and Finland, petitioning that their planned Nordic Nuclear Free Zone should include the Baltic states; several of the signatories were duly convicted of anti-Soviet agitation. 